\title{
Walory architektoniczno-krajobrazowe zamków w trwałej ruinie na przykładzie zamku w Czersku
}

\author{
Katarzyna Drobek \\ https://orcid.org/0000-0003-3599-1169 \\ k.drobek@pollub.pl \\ Katedra Konserwacji Zabytków, Wydział Budownictwa i Architektury, Politechnika Lubelska
}

\begin{abstract}
Streszczenie: Poniższy artykuł ma na celu przedstawienie walorów architektoniczno-krajobrazowe ruin zamku w Czersku. Są one przykładem zamków należących niegdyś do dynastii książąt mazowieckich. Ich ciekawa historia, malownicze położenie oraz duże wartości architektoniczne przyciągają wielu turystów. Dlatego też opisane zostały rozważania dotyczące zarówno walorów krajobrazowych jak i architektonicznych obiektu. Artykuł ten zawiera również opis historii warowni oraz zmian jego formy na przestrzeni wieków.
\end{abstract}

Słowa kluczowe: zamek, trwała ruina, krajobraz, Czersk

\section{Wstęp}

Ruiny zamkowe stanowią nieodzowny element polskiego krajobrazu kulturowego. Tworzą wartościowe uzupełnienie krajobrazu, wzbogacając je o znaczenie symboliczne, ukazując historię oraz uatrakcyjniając turystycznie okolicę. Niepowtarzalna architektura zamków stanowi o ich ogromnych walorach estetycznych, pomimo różnego stanu ich zachowania. Integralność z terenem stanowi o oryginalności i unikatowości każdej warowni. ${ }^{1}$ Elementami charakterystycznymi dla większości ruin zamkowych jest ich dominacja w otoczeniu. Współistnienie takich czynników jak wzgórza, rzeki, bagna decydowały o warowności założenia², dlatego też obecnie razem z tymi elementami ruiny zamków tworzą niezwykłe krajobrazy.

Zamek w Czersku należał niegdyś do dynastii książąt mazowieckich. Przez ponad 300 lat Mazowsze było państwem niezależnym, książęta mazowieccy rządzili nim bowiem od 1200 do 1526 roku. W trakcie ich panowania nastąpił dynamiczny rozwój tych ziem, ufundowali oni bowiem ponad 100 miast. Powstało również wiele zamków i kościołów, które obecnie posiadają ogromną wartość historyczną i w dzisiejszych czasach uznawane są za jedne z najważniejszych zabytków na Mazowszu. ${ }^{3}$

Teren Mazowsza posiadał jeden zasadniczy problem, jakim był jego nizinny charakter. Położony na obszarze Nizinie Środkowopolskiej, który charakteryzuje spora ilość rzek oraz ogrom wysoczyzn, które ograniczone są pradolinami rzek. To też warunkowało, że zamki sytuowane były w miejscach naturalnych wzniesień na stromym brzegu rzeki, tj. Warszawa, Czersk i Płock na brzegu Wisły czy Sochaczew położony nad Bzurą. Obiekty te powstawały niezależenie od siebie, dlatego też ciężko wyróżnić cechy stylowe dla zamków książąt mazowieckich.

1 Kosiński W., Byrski P., Architektura zamków - dominanta krajobrazowa i turystyczna, [w:] Ruiny żywe: adaptacja zabytków architektury do celów muzealnych: nowe inspiracje i funkcje dla Zamku w Janowcu: materiały z sympozjum naukowego z okazji 30-lecia Muzeum Zamek w Janowcu, Kazimierz Dolny - Janowiec, 2007, s. 51-59,

2 Bogdanowski J., Architektura obronna w krajobrazie Polski. Od Biskupina do Westerplatte, Warszawa-Kraków, 2002

3 https://szlakksiazat.pl/ [data odczytu: 28.09.2019] 
Niewątpliwie jednak wspólnym elementem jest posadowienie na fundamencie z kamieni polnych oraz użycie czerwonej cegły jako budulca. ${ }^{4}$

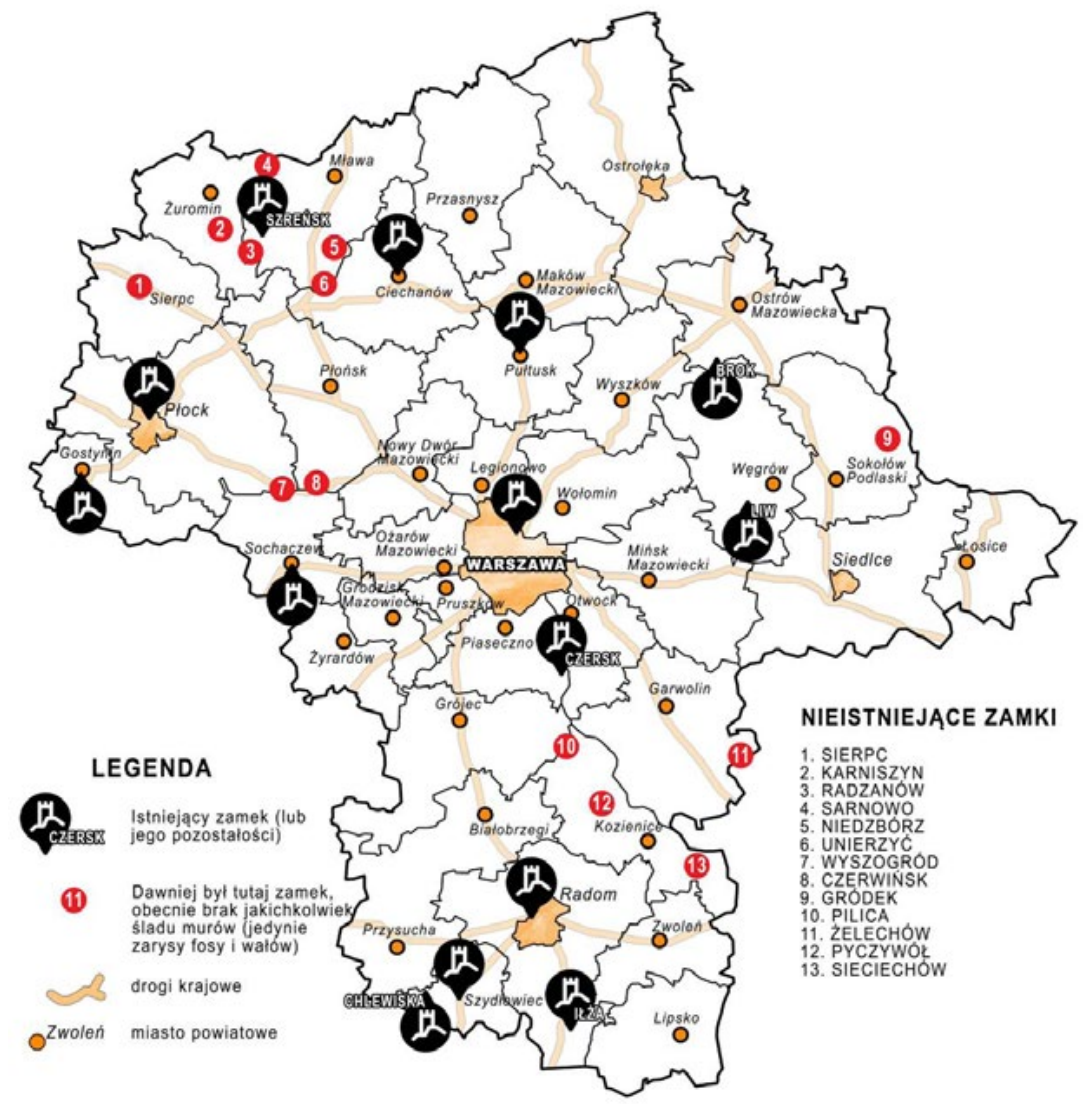

Ryc. 1. Mapa z zaznaczeniem zamków w woj. mazowieckim. Źródło: Opracowanie własne

\section{Ruiny zamku w Czersku}

Zamek w Czersku położony jest $35 \mathrm{~km}$ na południe od Warszawy oraz w odległości około $5 \mathrm{~km}$ od centrum Góry Kalwarii. Teren na jakim została usytuowana warownia posiada cechy położenia skarpowego. Obiekt został ulokowany na nadrzecznej skarpie; wysokim cyplu górującym nad pradoliną Wisły. Wzgórze zamkowe od strony dawnej doliny rzecznej posiada strome zbocze, które jest zupełnie wydzielone fosą ze skarpy. Od strony miasta teren, na którym usytuowano zamek nosi cechy nizinne. ${ }^{5}$ Budowla oddzielona fosą od strony zachodniej, jaką stanowią zabudowania Czerska.

Pierwotnie, w miejscu murowanego gotyckiego zamku, w XI w. znajdował się gród obronny, następnie drewniano-ziemna budowla pochodząca z przełomu XIII i XIV w. Obiekt ten zajmował podobny teren do obecnych ruin zamku, a przebieg jego murów dopasowany był do naturalnego ukształtowania wzgórza. Pod koniec XIV w. książę mazowiecki Janusz I rozpoczął budowę zamku murowanego, który stanowił jedną z jego najważniejszych rezydencji. Wieże, były elementami, które powstały jako pierwsze; wieża wschodnia - bramna, południowa - więzienna oraz zachodnia. W 1526 roku zamek staje się własnością królewską z powodu przyłączenia Mazowsza do Królestwa Polskiego. 


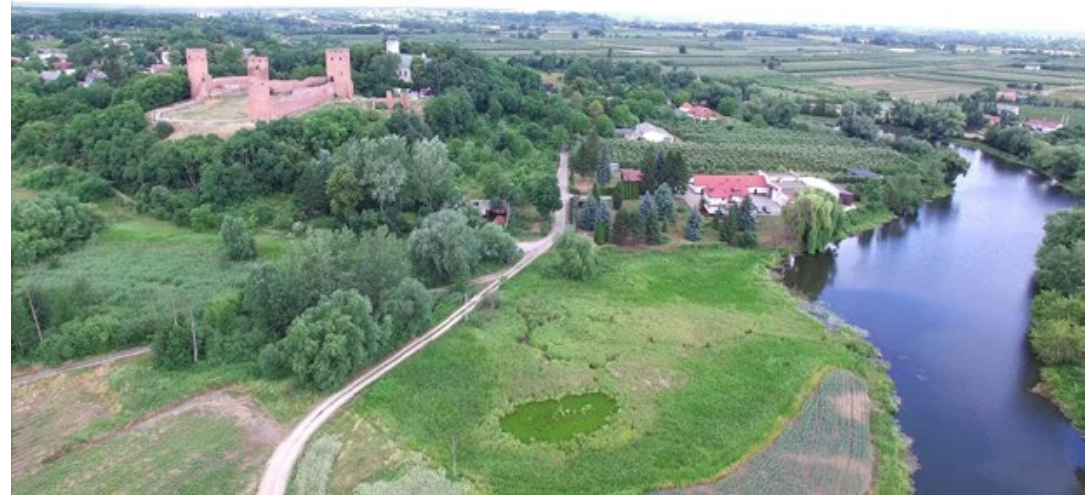

Ryc. 2. Ruiny zamku na tle Czerska i widok na jezioro Czerskie. Autor: Bartosz Szostak

W momencie wejścia warowni w 1547 roku w skład dóbr królowej Bony zabudowa drewniana dziedzińca zastępowana jest budowlami murowanymi. Na okres ten przypada budowa domu południowego oraz pałacu będącego rezydencją Bony. W roku 1656 zamek zdobywają Szwedzi pod wodzą Fryderyka margrabiego Badeńskiego, którzy opuszczając zamek dokonali licznych zniszczeń, zarówno zabudowań zamkowych jak i samego Czerska. W latach 1762-1766 przeprowadzona była częściowa restauracja zamku przez Marszałka Wielkiego Koronnego, starostę czerskiego Franciszka Bielińskiego w celu umieszczenia w nim sądu grodzkiego i ziemskiego. W tym czasie w miejsce mostu zwodzonego został wzniesiony most murowany, który istnieje do dnia dzisiejszego.

W latach 1907-1913 Kazimierz Skórewicz w ramach pracy Towarzystwa Opieki nad Zabytkami Przeszłości prowadził prace badawcze na zamku w Czersku. W ich trakcie wykonywano także prace wykopaliskowe. Działalność ta wznowiona była w 1927 - 1930 przez Skórewicza wraz z architektem Antonim Karczewskim. Odsłonięto wtedy fundamenty kościoła Św. Piotra. Z ich badań wynikało, że zamek powstał w XIII wieku. Wykonane przez nich opracowanie opisowe ma ogromną wartość jako ówczesna analiza obiektu. ${ }^{6}$

Kolejne opisy, uznawane za jedne z najwybitniejszych, wykonane zostały przez Adolfa Szyszko - Bohusza w 1912 roku. Według jego opracowania zamek czerski powstał w XIV w. Opublikowany przez niego artykuł zawierał analizę architektoniczno-funkcjonalną połączoną z inwentaryzacją oraz studium rekonstrukcji.

\section{Forma architektoniczna obiektu}

Zamek założony został na planie nieregularnego wieloboku, na który składa się 10 odcinków murów. Układ zamku częściowo został dostosowany do przebiegu wzgórza. Warownia została posadowiona na fundamentach kamiennych. Mury kurtynowe o średniej szerokości 1,8 metra oraz wysokości 8 metrów wykonano z cegły. Założenie to powstało w systemie wielowieżowym w odmianie wież zwielokrotnionych ${ }^{7}$. W jego skład wchodziły dwie okrągłe wieże, wieża bramna oraz mury kurtynowe otaczające ogromny dziedziniec ze znajdującym się na nim kościołem św. Pawła i dwoma budynkami mieszkalnymi, które pierwotnie były zabudową drewnianą i w późniejszym czasie zamieniono je na murowane. Początkowo wysokość wszystkich wież była takiej samej wysokości jak murów. 


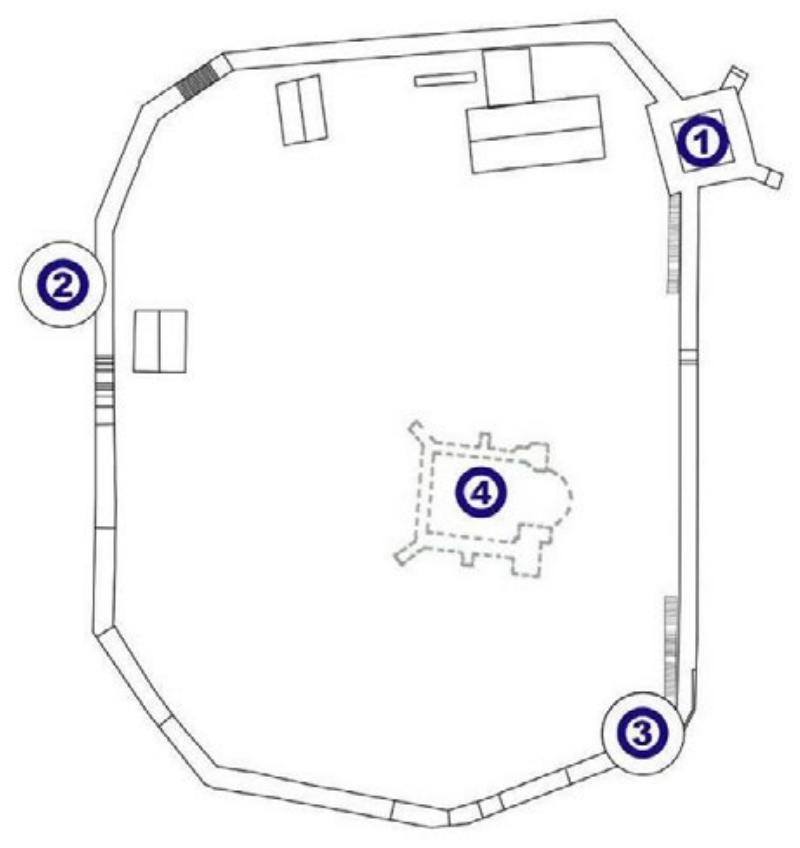

Ryc. 3. Plan zamku w czersku 1. Wieża bramna, 2. Wieża zachodnia, 3. Wieża więzienna, 4. Relikty kolegiaty św. Piotra

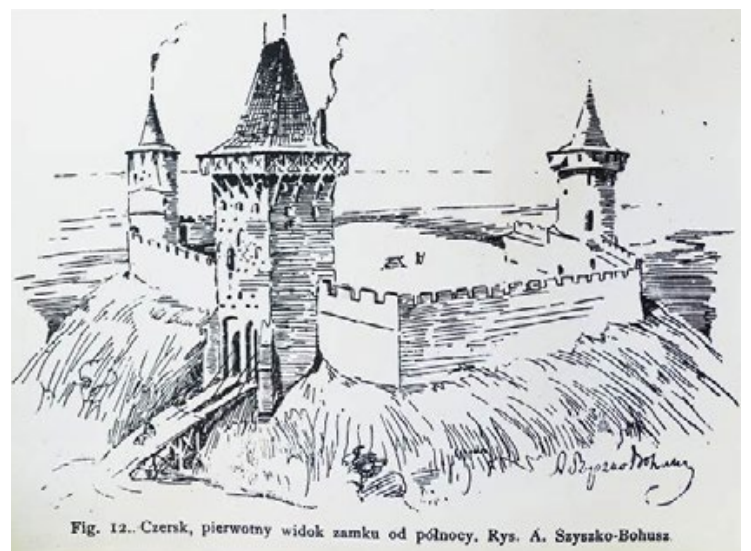

Ryc. 4. Rekonstrukcja zamku, 1912 r., Autor: A. Szyszko-Bohusz

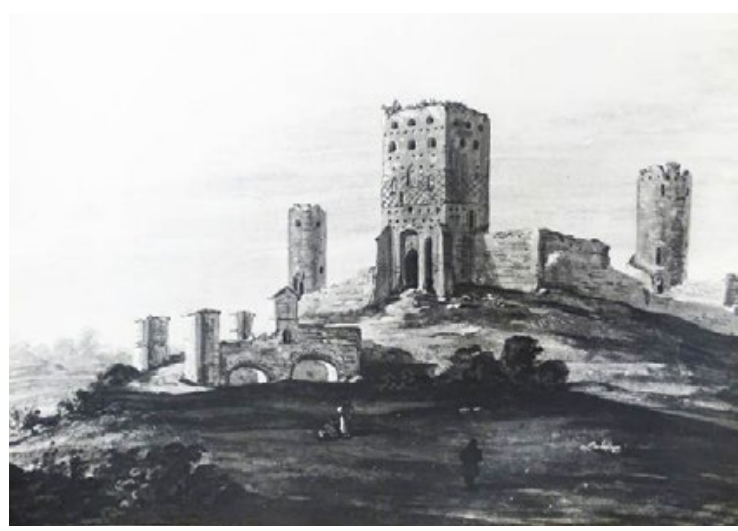

Ryc. 5. Widok od strony północno-wschodniej, Autor: K. Stronczyński, 1961 r.

Źródło: oprac. I. Galicka, fot. R. Kazimierski, red A. Grzybkowski, Dokumentacja architektoniczno-konserwatorska, Archiwum MWKZ

Pięciokondygnacyjna wieża bramna znajdująca się we wschodniej części warowni, przed linią murów kurtynowych założona została na planie kwadratu o boku 8,5 metra. Narożniki budowli stanowią siedmiometrowe wspierające szkarpy, między nimi znajdują się dwa otwory zakończone łukami odcinkowymi. Mniejszy otwór stanowił przejście piesze, większy był bramą wjazdową. Z początku dojazd do zamku odbywał się dwoma drewnianymi i unoszonymi zwodzonymi mostami, następnie w 1762 roku zastąpiono je jednym, murowanym mostem o dwóch półokrągłych arkadach. Wejście do wieży prowadziło przez drewniane schody ulokowane wzdłuż wschodniego muru. Piątą kondygnację wieży dobudowano najprawdopodobniej za czasów panowania królowej Bony i w tym czasie zwieńczona była drewnianymi hurdycjami. 

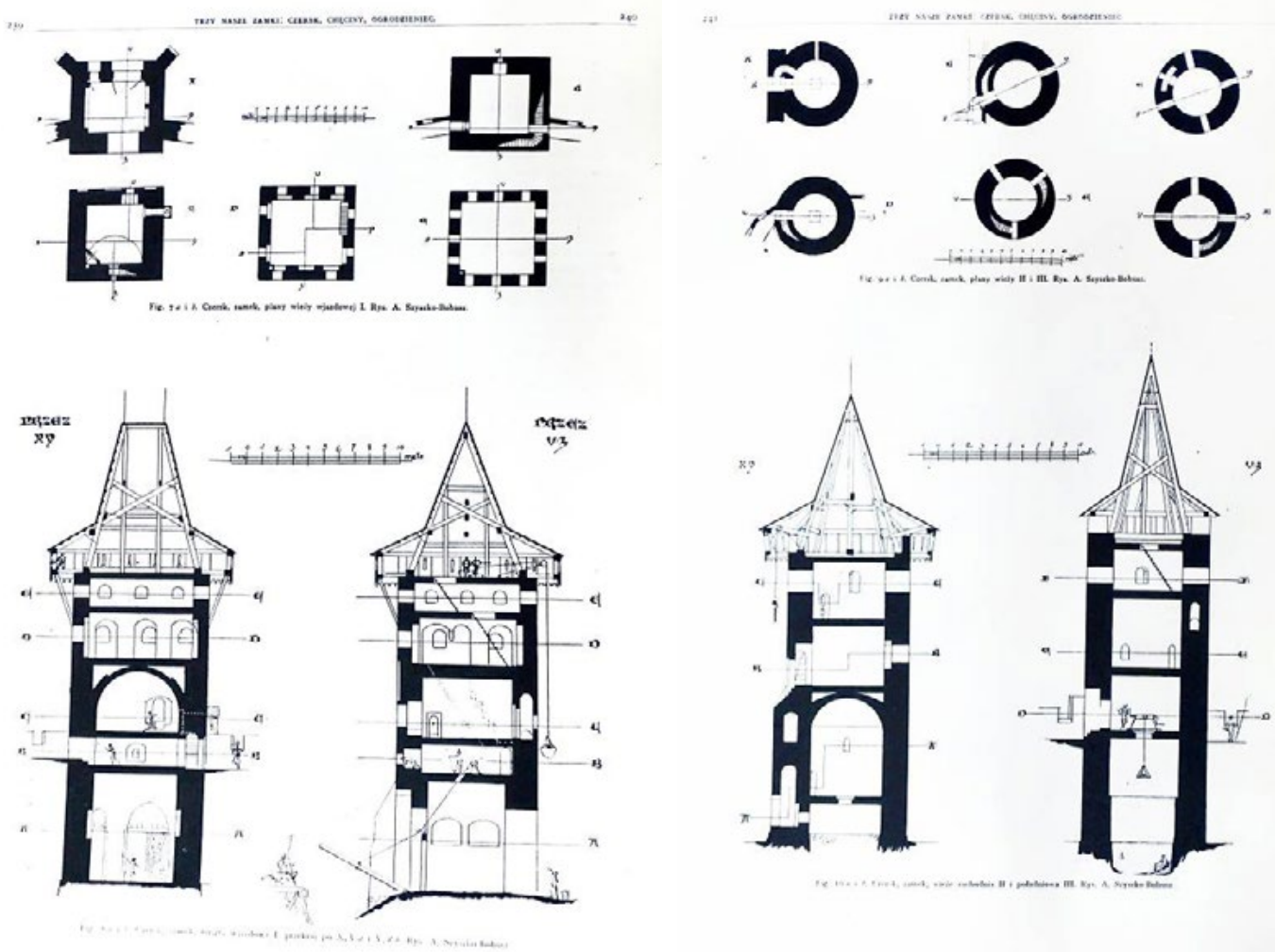

Ryc. 6. Czersk, wieża bramna - rzuty i przekroje (lewa strona); wieża zachodnia i południowa - rzuty i przekroje (prawa strona), Autor: A. Szyszko-Bohusz, Źródło: oprac. I. Galicka, fot. R. Kazimierski, red A. Grzybkowski, Dokumentacja architektoniczno-konserwatorska, Archiwum MWKZ

Wieża południowa prawie w całości znajdowała się wewnątrz obwodu murów. Osiągnęła wysokość 24 metrów i założona została na planie koła. Prawdopodobnie posiadała znikome znaczenie obronne. Nazywana była również wieżą więzienną, ponieważ we wnętrzu, na jej dnie znajdowało się więzienie. Schody prowadzące na górę wieży znajdowały się w grubości muru. W czasach współczesnych powstała kładka przechodząca przez jej wnętrze. Druga wieża okrągła - zachodnia, w całości została usytuowana wewnątrz obwodu murów. Z niej odbywała się obrona przed atakiem z przedpola od strony zachodniej.

Obecnie zamek jest malowniczą ruiną znajdującą się na wiślanej skarpie. Z całej warowni zachowały się trzy wieże, mury obronne północne i wschodnie osiągające wysokość 6 metrów oraz XVIII-wieczny most ceglany. Mur obronny znajdujący się w południowej części został najprawdopodobniej rozebrany podczas I wojny światowej. Odtworzony został w formie niskiego muru z opoki podczas prac remontowych w 2013 roku. Nie zachowały się również drewniane konstrukcje stropów oraz dachów. Na terenie dziedzińca znajdują się odkopane fundamenty kolegiaty św. Piotra, natomiast zabudowa mieszkalna nie została zachowana. Mury warowni zostały częściowo przemurowane cegłą, która odróżnia się od historycznej fakturą i barwą od historycznej cegły gotyckiej.

Na licu wież znajdują się charakterystyczne elementy dekoracyjne ułożone $w$ fryzy romboidalne wykonane z cegły zendrówki o kolorze brązowo-czarnym. W murach widoczne są również gniazda po miejscach, w których osadzone były drewniane belki oraz otwory maculcowe, charakterystyczne dla budownictwa średniowiecznego, będące pozostałościami po montażu drewnianych rusztowań. 


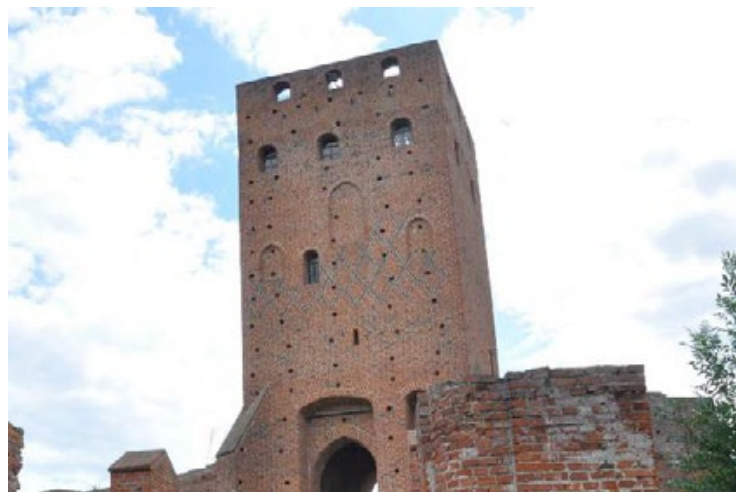

Ryc. 7. Widok na dziedziniec od strony południowej. Autor: Katarzyna Drobek

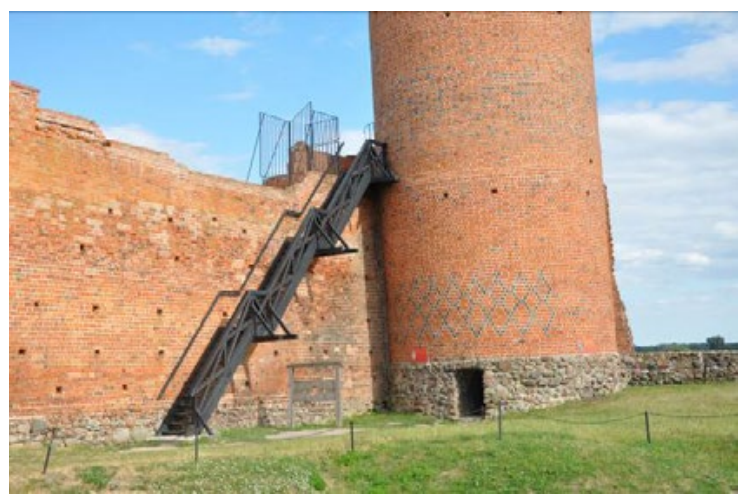

Ryc. 8. Widok na dziedziniec od strony południowej. Autor: Katarzyna Drobek

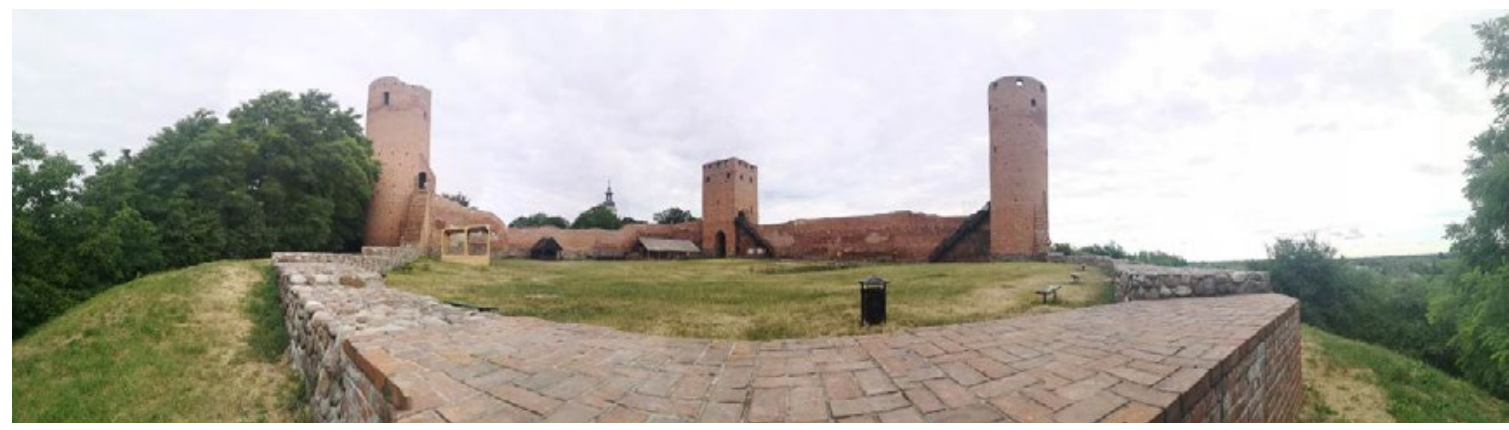

Ryc. 9. Widok na dziedziniec od strony południowej. Autor: Katarzyna Drobek

\section{Uwarunkowania krajobrazowe}

Czersk jest to jedno z najstarszych miast Mazowsza, które dawniej było stolicą księstwa dzielnicowego. Obecnie jest to wieś znajdująca się w gminie Góra Kalwaria, powiecie piaseczyńskim i województwie mazowieckim. Prawa miejskie uzyskało w 1350 roku. Jego średniowieczny układ urbanistyczny wraz z rynkiem, siatką ulic oraz cmentarzem kościelnym wpisany został do rejestru zabytków (nr rej. 1010/690/62 z 12.04.1962). Położony jest na obszarze makro-regionu, który nazywany jest Niziną-Środkowo-Mazowiecką. W jego obrębie znajdują się dwa mezoregiony, z czego Czersk znajduje się na terenie Doliny Środkowej Wisły - odcinek od Warszawy po Puławy. W jego skład wchodzi wydmowy taras piaszczysty oraz niższy łąkowy teras zalewowy, który na wysokości Czerska ma szerokość około $10 \mathrm{~km}$ i utworzony jest z szerokich terasów Wisły zbudowanych z mad. ${ }^{8}$ Zabudowania w Czersku stanowią przeważnie domy jednorodzinne wraz budynkami gospodarczymi. Z czerskiego rynku, zza niskiej zabudowy można dostrzec wyłaniające się wieże zamku. Dojście na zamek odbywa się bezpośrednio przez teren kościoła parafialnego.

Ruiny Zamku Książąt Mazowieckich w Czersku są elementem dominującym w krajobrazie miejscowości. Ulokowane są na skarpie wiślanej, która zakończona jest trzema wzgórzami. Środkowe zajmuje obecnie kościół parafialny pw. Przemienienia Pańskiego, południowe zaś zamek. Na wschód od wzgórza zamkowego znajduje się wąskie jezioro, uznane za pomnik przyrody - jezioro Czerskie, które zajmuje miejsce w starorzeczu Wisły. Bagniste brzegi jego dopływu, czyli rzeki Czarnej stanowiły naturalne i niezwykłe korzystne warunki obrony przed natarciami ze strony północnej i wschodniej. 


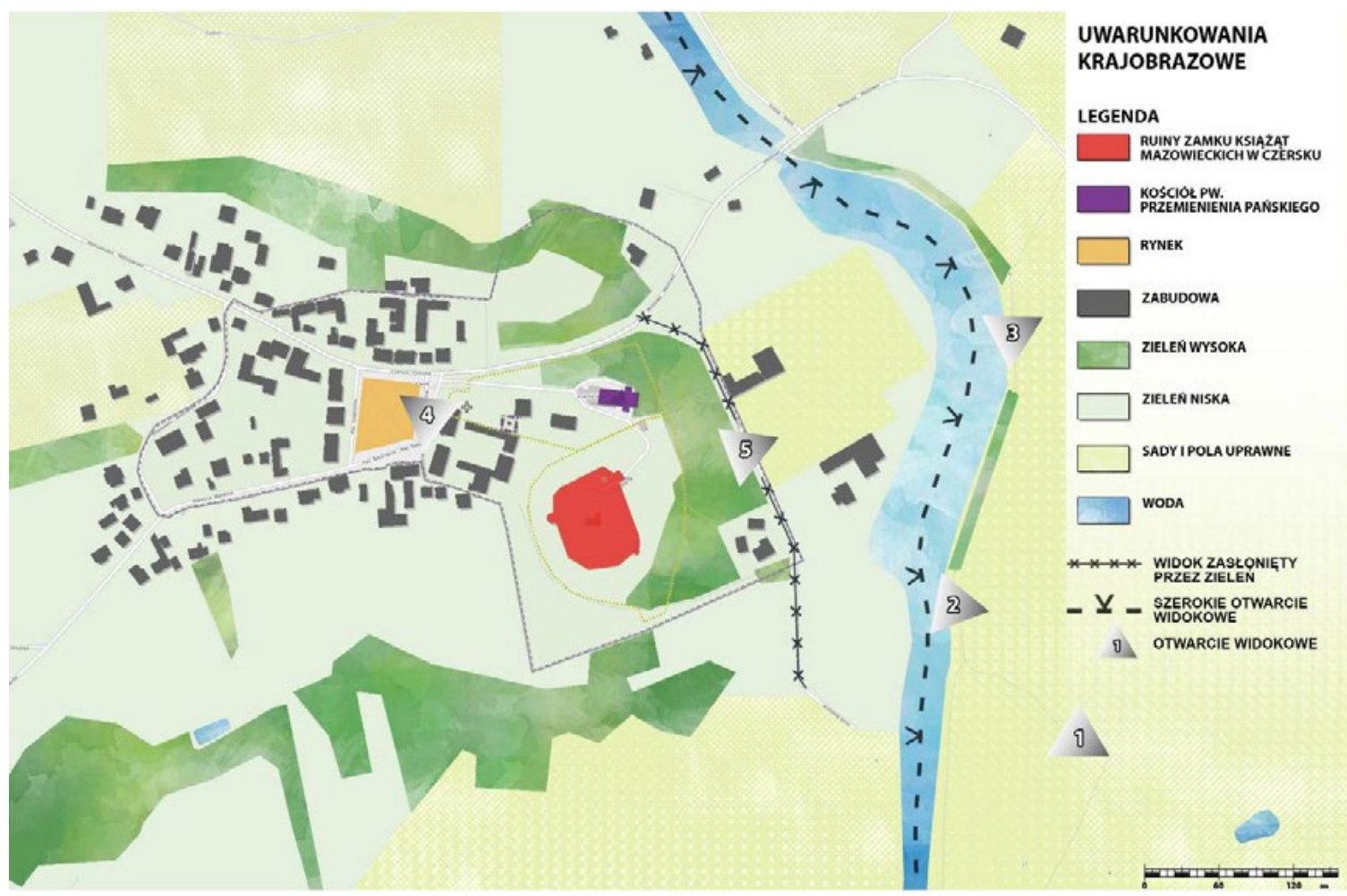

Ryc. 10. Uwarunkowania krajobrazowe zamku w Czersku. Źródło: opracowanie własne na podkładzie https://mapy.zabytek. gov.pl/nid/

Przedpole ekspozycji stanowią rozległe pola, łąki i sady. Jezioro Czerskie jest natomiast lustrem, w której tafli odbija się urokliwa okolica. Wzdłuż osi zbiornika wodnego rozciąga się szerokie otwarcie widokowe na wzgórze zamkowe. Ulica Królowej Bony, biegnąca u podnóża skarpy nadwiślańskiej, która również jest położona niemalże równolegle względem jeziora Czerskiego, ma zasłonięty widok na zamek ze względu na wysoką zieleń porastającą zbocza skarpy. Zaledwie w dwóch miejscach można dostrzec fragmenty wież zamku.

Niegdyś, ze względów obronnych wzgórza zamkowe porastała jedynie roślinność niska. Obecnie skarpa wschodnia, południowa i zachodnia pokryta jest sporej wysokości drzewami. Powoduje to przesłanianie widoku na zamek czerski. W panoramie jest on widoczny jedynie z kilku punktów. Przykładowo od strony jeziora Czerskiego jest jedynie kilka miejsc, z których warownia widoczna jest w pełnej okazałości.

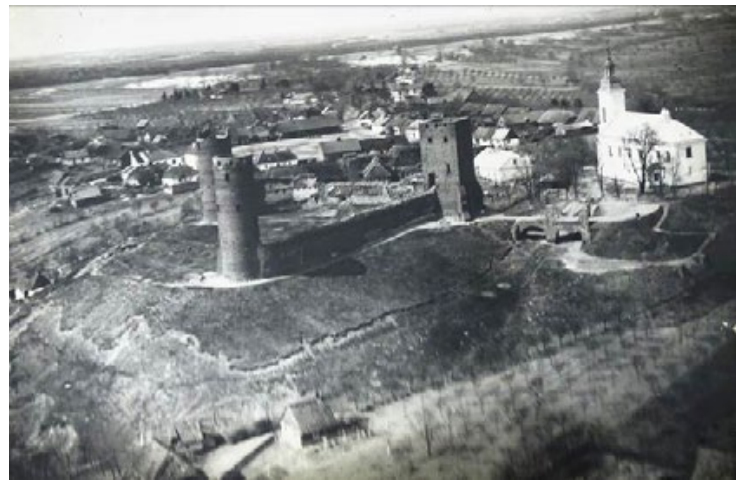

Ryc. 11. Zdjęcie lotnicze, widok od strony poł.-wsch., Autor: por. Wasilewski, Źródło: oprac. I. Galicka, fot. R. Kazimierski, red A. Grzybkowski, Dokumentacja architektoniczno-konserwatorska, Archiwum MWKZ

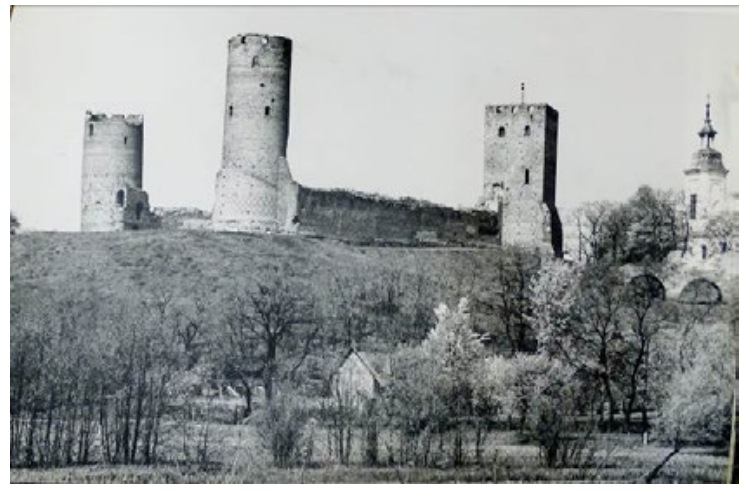

Ryc. 12. Widok od strony poł.-wsch., 1966 r., Autor: R. Kazimierski, Źródło: oprac. I. Galicka, fot. R. Kazimierski, red A. Grzybkowski, Dokumentacja architektoniczno-konserwatorska, Archiwum MWKZ 


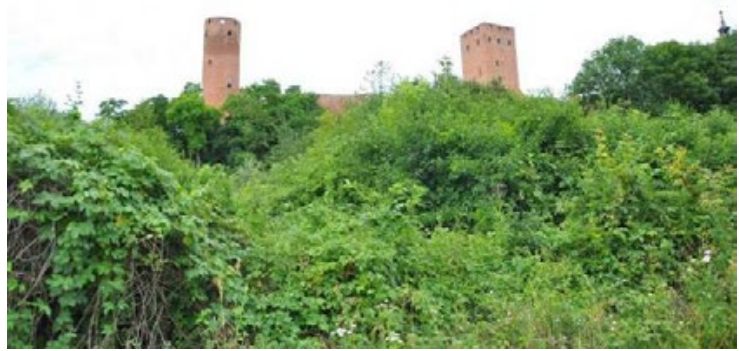

Ryc. 13. Widok na zamek od ul. Królowej Bony, Autor: Katarzyna Drobek

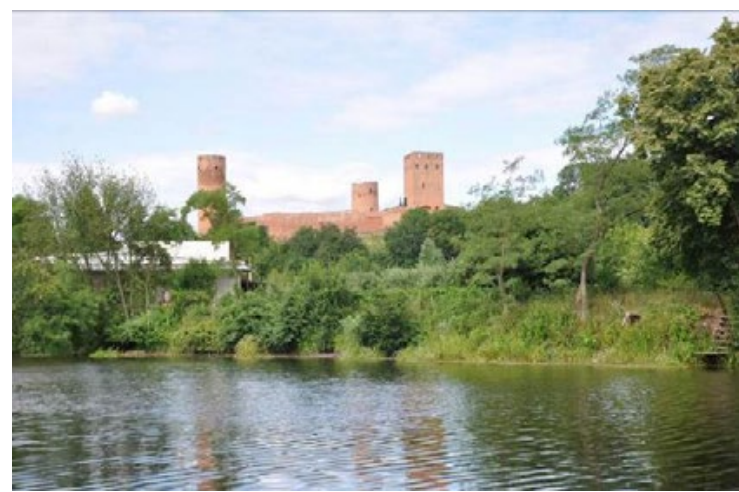

Ryc. 14. Widok na zamek od strony jeziora Czerskiego. Autor: Katarzyna Drobek

Wzgórze zamkowe, oddalone obecnie o około 2 kilometry od koryta Wisły. Wspominana wcześniej obecność terasów oraz starorzecza pozostawiła na tym terenie bardzo żyzne warstwy mad. Już od czasów panowania królowej Bony, na okolice te stanowią ogrody, sady i winnice, na które rozpościera się widok z tarasów widokowych wież zamkowych ${ }^{9}$.

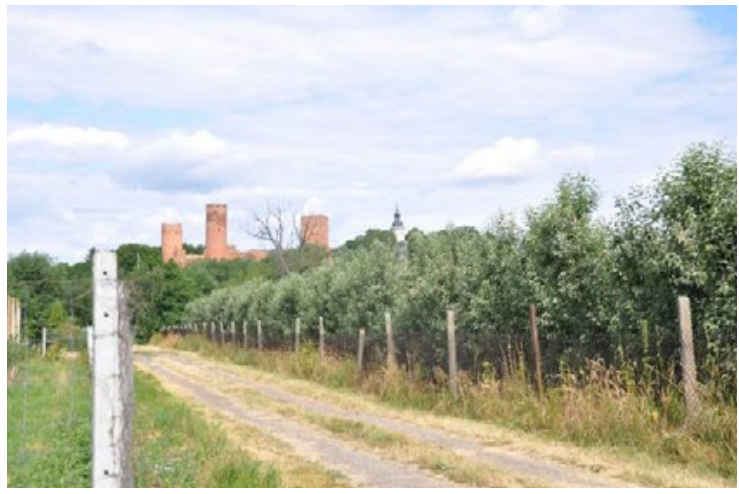

Ryc. 15. Widok na zamek od strony sadów, ul. Pólko. Autor: Katarzyna Drobek

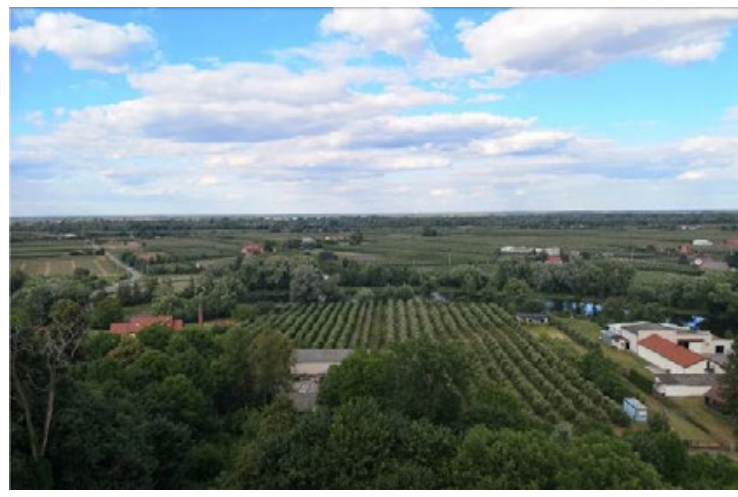

Ryc. 16. Widok na zamek od strony jeziora Czerskiego. Autor: Katarzyna Drobek

\section{Wnioski}

Ruiny Zamku Książąt Mazowieckich w Czersku posiadają ogromną wartość architektoniczno-krajobrazową. Jeżeli chodzi o architekturę obiektu, można stwierdzić iż jego forma, która bezpośrednio wynika z funkcji, jaką dawniej pełnił zamek jest podstawową i najważniejszą jego wartością. Przede wszystkim budowla ta jest dokumentem przeszłości, jest nośnikiem historii oraz stanowi jej materialne odzwierciedlenie. Dlatego też jego znaczna wartość naukowa oraz ogromne walory historyczne niewątpliwie powinny być przedmiotem ochrony. Jak już wcześniej wspomniano, zamek posiada malownicze położenie na wzgórzu, u którego podłoża rozciąga się pradolina Wisły. Duża ekspozycja obiektu w krajobrazie sprawia, że obiekt jest tak interesujący. Ze względu na to należy więc zwrócić uwagę na ochronę integralności przedpola ekspozycji. Niewątpliwe walory krajobrazowe tychże ruin zamkowych są kolejnym czynnikiem, po ogromnych wartościach historycznych obiektu, jakie przyciągają wielu turystów. Pomimo niezbyt wielkiej ilości atrakcji, rocznie zamek odwiedza aż około 44 tysięcy turystów. Ma na to również wpływ doskonała lokalizacja względem pobliskiej Warszawy oraz obecność kilku 
tras rowerowych przebiegających przez Czersk. Dodatkowo olbrzymie dziedzictwo kulturowe zamku oraz samej miejscowości pozytywnie wpływają na ożywienie tego miejsca.

\section{Bibliografia}

[1] Architektura gotycka w Polsce, red. T. Mroczko i M. Arszyński, Warszawa 1995.

[2] Bogdanowski J., Trwała ruina zamku jako problem konserwatorsko-krajobrazowy, [w:] Ochrona Zabytków, 1977, nr 30/1-2 (116-117), s. 27-46.

[3] Bogdanowski J., Architektura obronna w krajobrazie Polski, PWN Wrocław - Kraków 1996.

[4] Chlebowska D., Trwała ruina w Polsce koniecznym świadkiem historycznego krajobrazu, [w:] Wiadomości Konserwatorskie, nr 16/2004, s. 76-83.

[5] Frydryczak B., historyczne formy waloryzacji ruin[w:] Studia Europaea Gnesnensia, 2011, nr 3, s. $175-194$.

[6] Guerquin B., Zamki w Polsce, Warszawa 1984.

[7] Jakubiak M., Zamki na Mazowszu: historia, stan zachowania i wykorzystania, [w:] MAZOWSZE Studia Regionalne, 2011, nr 7, s. 117-124.

[8] Kajzer L., Kołodziejski S., Salm J., Leksykon zamków w Polsce, Warszawa 2012.

[9] Kocańda P., Ruiny zamków jako przykład obiektów muzealnych na „wolnym powietrzu”. Wstęp do problematyki i historia zainteresowań do 1914 roku, [w:] Młoda Muzeologia, 2016, t. I, s. 34-46.

[10] Kosiński W., Byrski P., Architektura zamków - dominanta krajobrazowa i turystyczna, [w:] Ruiny żywe: adaptacja zabytków architektury do celów muzealnych: nowe inspiracje i funkcje dla Zamku w Janowcu: materiały z sympozjum naukowego z okazji 30-lecia Muzeum Zamek w Janowcu, Kazimierz Dolny - Janowiec 2007, s. 51-59.

[11] Lewicki J., Ochrona i konserwacja ruin - przemiany metod na przykładzie Mazowsza, [w:] Historyczne ruiny - ochrona, użytkowanie, zarządzanie, nr 6, 2018, s. 117-134.

[12] Molski P., Czynniki kulturowe i czynniki pozakonserwatorskie a postępowanie z zamkami w ruinie. Wnioski, [w:] Ochrona i konserwacja ruin zamkowych - wybrane problemy i przykłady, Warszawa - Lublin 2013, s. 41-47.

[13] oprac. Galicka I., fot. Kazimierski R., red Grzybkowski A., Dokumentacja historyczno-architektoniczna, Archiwum WKZ w Warszawie, 1967.

[14] Teodorowicz-Czerepińska J., Zamki Kazimierza Wielkiego na Lubelszczyźnie, Kalendarz Lubelski, 1972.

[15] Przyłęcki M., Trwałe ruiny historycznych obiektów w krajobrazie miast, [w:] Architektura Krajobrazu, 2007, nr 3, s. 25-34.

[16] Stępień P. M., Wartości krajobrazowe związane z ruinami zamku Czorsztyn i potrzeba ich ochrony, [w:] Pieniny - Przyroda i Człowiek, 2008, nr 10, s. 105-117.

[17] Szmygin B., Ochrona historycznych ruin - założenia do teorii i praktyki, [w:] Historyczne ruiny - ochrona, użytkowanie, zarządzanie, nr 6, 2018, s. 191-200.

[18] Malawska I., Zamki w Polsce - problem określenia zasobu, [w:] Ochrona Zabytków 4/2007, Warszawa 2007, s. 83-86.

[19] Wieclawowicz-Gyurkovich E., Historyczne zamki a współczesność, [w:] Przestrzeń i Forma, 2009, nr 12, s. 76-83.

[20] Zagrodzki T., Czersk, zamek i miasto historyczne, Warszawa 1996.

\section{Strony internetowe}

[21] http://www.gorakalwaria.pl/ [dostęp 28.09.2019]

[22] https://medievalheritage.eu/ [dostęp 28.09.2019]

[23] http://www.czersk.org/ [dostęp 28.09.2019]

[24] https://zabytek.pl/ [dostęp 28.09.2019]

[25] https://zamki.res.pl/ [dostęp 28.09.2019]

[26] http://zamkipolskie.com/ [dostęp 28.09.2019]

[27] http://www.zamekczersk.pl/ [dostęp 28.09.2019] 